\title{
Editorial: Begin, Again
}

\author{
PAUL RA E
}

This is my first issue as senior editor of Theatre Research International. That the journal and I are almost exactly the same age is at once thrilling and a little unsettling. One feels both the weight of tradition, and the sense of mission and possibility that contemporaries can share. Indeed, looking through back issues, I am struck by how integrally TRI has both reflected and driven changes in performance practice and scholarship that I recognize from my own intellectual development. I began my undergraduate studies at Bristol University Drama Department - publisher, from 1959 to 1974, of one of TRPs two precursors, New Theatre Magazine (the other being Theatre Research/Recherches théâtrales). That was in 1992, in the same year an editorial by Claude Schumacher highlighted a reorientation of the journal away from text-based drama towards 'the theory of theatre practice'. 'I left the UK to make theatre (and a life) in Singapore in 1996, just as the journal began notably to expand its international scope. And I commenced my $\mathrm{PhD}$ on cosmopolitanism and performance in 2001, at the same time as Brian Singleton's overhaul of the journal's structure and focus set the internationalizing standard for the publication that exists today. That year, I made my first trip to Australia, to present on a panel for emerging scholars at a conference of the International Federation for Theatre Research (IFTR, the organization with which this publication is affiliated), hosted by the University of New South Wales. Subsequent conference participation brought me into contact with TRI editors Christopher Balme, Freddie Rokem, Elaine Aston and Charlotte Canning, and, courtesy of the IFTR member's subscription, the material they were publishing.

Now I am back in Australia, this time at the University of Melbourne, contemplating in turn the challenge that confronts every incoming editor of TRI: how to do justice to its international remit. This is where autobiography falls short. Both my own trajectory and that of the journal are as much reflective of larger geopolitical shifts in global economic and cultural influence as they are of individual choice or editorial policy. It is the job of the journal to track these developments as they are addressed and enacted by theatre and performance. This is exciting, but also sobering. Claims about the scale of international trends or the significance of globalized practices come easily, relative to the hard work of conducting research, writing it up and disseminating it to a readership. This is especially the case for many of TRI's authors and readers. The difficulties of attaining competence in academic English, wide variations in scholarly convention, and limited access to research resources characterize an uneven scholarly landscape that can all too easily be smoothed over with a blanket term like 'international'. Moreover, the relationships among the forces that shape this landscape, the rebalancing of global power and the progressive values represented by TRI are not straightforward. Global economic pressures mean that 
academic publishing is increasingly bound up with the instrumentalization of scholarly enquiry in some societies, and with the authoritarian production and management of information in others.

There is, therefore, no room for naivety about the sometimes contradictory ends that journals such as TRI can serve for individuals and institutions. But nor can we allow ourselves the luxury of cynicism, for to do so would be to fail the theatre-makers who labour so mightily to transfigure the world. It is in this context that I turn to a recent discussion of the term 'international' by Janelle Reinelt. She examines the political and legal contexts of its coining and early usage in English, weighs its interpretive value against other terms such as 'global' and 'transnational', and makes the case for 'international' as both 'a descriptor and a political commitment'. International performance scholarship, she argues, 'would then pursue interconnections and cooperation across cultural and national lines, developing cosmopolitan methodologies and perspectives with regard to our national and local scholarship, and seek to understand and critique the complex and ever-shifting global context within which we live and work'. ${ }^{2}$

I confess that I am not quite as convinced as Reinelt that the nation state remains so dominant a factor in the global circulation of cultural agents and practices as to deserve the explanatory emphasis she grants it. Nevertheless, the vision of an international performance scholarship that Reinelt outlines cuts to the quick of what TRI can and should do - not only at the broad level of editorial policy, but as a rule of thumb for the countless detailed decisions that comprise day-to-day editorial practice. For it is there, I am fast learning, that the substantive internationalism of a journal like TRI stands or falls. Taken together, the five articles I am pleased to introduce in this particular issue leave broad swathes of the globe unrepresented. But in a variety of ways, they give expression to a granular, indeed lived, international sensibility.

Elaine Aston's 'Agitating for Change' began life as a keynote speech at Performing Democracy, the 2015 IFTR conference in Hyderabad, India. I was struck at the time by Elaine's ability to outline a relation between feminism and theatre that was addressed to an international audience, but reflected the details and idiosyncrasies of British public life. In the article, she draws on three very different performances - a new play, a flash mob that is part of a global activist movement, and a West End musical - to assemble a 'network of resistance' to neoliberal policies and social developments. By elaborating on both the contextual and the performance details of her chosen events, while drawing with admirable clarity on the methodological and conceptual provocations of political theorists such as Chantal Mouffe, Aston draws attention to a highly distinctive network of associations, while leaving enough scope for her readers to extend many of her lines of thought into new, and perhaps unforeseen, configurations in other times and places.

Indeed, just such a configuration may be found in Rivka Eisner's 'Remember September', which shares a similarly cumulative approach to tracing patterns of political resistance through a complex performative event. In 2008, a group of Burmese and Vietnamese artists and a phalanx of volunteers created a sugar temple for the Singapore Biennale, entitled September Sweetness. Eisner painstakingly reconstructs the process of constructing this fragile and allusive installation, around which a range of performative actions and political meanings began to accumulate. In particular, Eisner focuses on the 
role of the temple in commemorating the 'Saffron Revolution', which had arisen quite precipitously in Burma as a protest movement a year before, and been brutally repressed by the military junta.

Today, an improved political situation in the country means that Eisner feels it is possible to elaborate on this event in ways that were previously unwise. In so doing, she conducts an exercise in transnational remembering about a process of displaced commemoration, something that might also be said about the focal event of Jennifer Goodlander's 'Sbeik Thom at the Season of Cambodia Festival'. Like Eisner's example, the shadow puppet performance in question took place under the aegis of an international showcase in a global city. Where the commemorative work of September Sweetness was notably understated, however, publicity around the sbeik thom performance and its siting at the former World Financial Center, which was damaged in the attacks on the World Trade Center in September 2001, pointed to histories of genocide in the case of Cambodia and terror in New York. Goodlander outlines some of the complex ways these associations sat alongside and were inflected by numerous practical details of the performance and its narrative, as well as reflecting on the trajectory of the puppet troupe once they returned from New York to their home town of Siem Reap.

Connections between memories and materials also ground - in some senses literally - the third of this issue's trilogy of articles focusing on South East Asia, Miguel Escobar Varela's 'Heirlooms of the Everyday'. Escobar Varela profiles the innovative puppet performances of the late Slamet Gundono, a remarkable figure adept at creating playful and provocatively revisionist accounts of the Indonesian wayang kulit (shadow theatre) canon in which he was trained. Escobar Varela notes that Gundono's work can be described as an instance of 'material performance' in ways that will be recognizable to those familiar with postdramatic practices. At the same time, however, he explains some of the specifically Indonesian and Javanese dimensions of the work, particularly the treatment of mundane objects as invested with the force of pusaka, or heirlooms, which enabled Gundono to mediate between conventional audience expectations and contemporary themes ranging from women's rights, through religious tolerance, to climate change.

The final article of the issue, Adele Senior's 'Beginners On Stage', returns us to the British context that Aston introduced, and projects us beyond a thematic preoccupation with memory and the past, into a confrontation with futurity. Senior draws Hannah Arendt's ideas about the political force of new beginnings into dialogue with the European trend for contemporary performances featuring children. Arendt rooted her understanding of political action as a decisive intervention into the public sphere in the concept of 'natality', but excluded birth itself, and the actuality of children, from such a domain. By shifting her attention to the stage, Senior asks what children themselves have to tell us about the nature of new beginnings. In so doing, she raises pertinent questions about the ethics of child-adult relationships, as well, in a nod to some of the second-wave feminist preoccupations that Aston invokes in her article, as the social and political circumstances within which those relationships are practised in advanced industrial societies. 
I am not superstitious, by and large, but I do hope that featuring an article on beginnings in the first issue under my editorship proves propitious. Together, the analyses collected here indicate how Reinelt's vision of an international performance scholarship that is interconnected, reflective of diverse scholarly perspectives and addressed to changing global circumstances can be worked out in practical terms. The articles trace complex circulations of people, objects and ideas across national borders, while remaining centrally preoccupied with the forms they take in specific localities. The conceptual and methodological approaches at work here are astute and innovative, based on close-quarters engagement with artists, their work and the circumstances in which audiences have encountered it. Working on such material as an editor has been immensely stimulating, and, with incisive support from the new associate editor of TRI, Fintan Walsh of Birkbeck, University of London, and assistant editor Sarah Balkin, my colleague at the University of Melbourne, more fun than such an activity is probably supposed to be. We could not have got to this stage in one piece without invaluable advice from my predecessor as senior editor, Charlotte Canning, and her assistant, Lydia Nelson. In the course of preparing this issue, I frequently consulted Charlotte's fabulous final issue (October 2015), which will remain a testament to her editorial achievements as well as to her unerring eye for scholarly detail, and ear for a good story.

NOTES

Claude Schumacher, 'Editorial', Theatre Research International, 17, 1 (March 1992), p. 1.

Janelle Reinelt, 'International/ism', in Bryan Reynolds, ed., Performance Studies: Key Words, Concepts and Theories (London and New York: Palgrave Macmillan 2014), pp. 281-8, here p. 287. 